\title{
Staphylococcus saprophyticus in the aetiology of nongonococcal urethritis
}

\author{
B. HOVELIUS, I. THELIN, AND P.-A MÅRDH
}

From the Department of Medical Microbiology, University of Lund; and the Department of Dermatology and Venereology, University Hospital, Lund, Sweden

SUMMARY The occurrence of Staphylococcus saprophyticus, Chlamydia trachomatis, and Neisseria gonorrhoeae in urethral specimens of 252 men attending a venereal disease clinic was studied. When using a selective broth medium containing novobiocin and nalidixic acid, Staph. saprophyticus was isolated from $20.8 \%$ of 178 men with symptoms of urethritis and from $14.9 \%$ of 74 men without such symptoms. Staph. saprophyticus was found significantly less often in controls $(7.1 \%$ of 56$)$ than in the men with symptoms of urethritis. In the 35 men from whom Staph. saprophyticus was recovered more than 10 leucocytes per high power field in urethral smears occurred more often than in those from whom this organism, or either of the other two agents, were not isolated. No differences were found in the symptoms reported by the men harbouring Staph. saprophyticus or C. trachomatis or those with negative cultures. The results of the present study tend to suggest that Staph. saprophyticus is the aetiological agent of some cases of nongonococcal urethritis.

\section{Introduction}

In recent years $25-45 \%$ of all cases of nongonococcal urethritis (NGU) in men have been attributable to Chlamydia trachomatis infection (Holmes et al., 1975; Oriel et al., 1976; Alani et al., 1977; Bowie et al., 1977a; Ripa et al., 1978). Herpes simplex virus, Candida albicans, and Trichomonas vaginalis are responsible for some $(5-10 \%)$ cases of NGU (Catterall, 1975; Holmes et al., 1975).

There is also some evidence that Ureaplasma urealyticum is the pathogen responsible for some cases of NGU. An association between a primary episode of NGU and $U$. urealyticum has been claimed on the basis of therapeutic studies and quantitative cultures of the organism (Prentice et al., 1976; Bowie et al., 1977a).

Staphylocoicus saprophyticus (earlier named Micrococcus, subgroup III) is known to be a frequent cause of acute cystourethritis in young adult women (Maskell, 1974; Sellin et al., 1975). Staph. saprophyticus, like Staphylococcus cohnii and Staphylococcus xylosus, differs from other

Address for reprints: Dr P.-A. Mårdh, Department of Medical Microbiology, University of Lund, Sölvegatan 23, S-223 62 Lund, Sweden

Received for publication I March 1979 coagulase-negative staphylococcal species (for example, Staphylococcus epidermidis) in being less susceptible to novobiocin (minimum inhibitory concentration $>2 \cdot 0 \mu \mathrm{g} / \mathrm{ml}$ ).

In the present study, we investigated the occurrence of Staph. saprophyticus, C. trachomatis, and Neisseria gonorrhoeae in urethral specimens of men attending a venereal disease clinic. For comparison male medical students and laboratory staff were also studied. A selective culture medium was developed for the isolation of Staph. saprophyticus.

\section{CLINIC POPULATION}

Groups 1 and 2

The patients consisted of 252 men between 15 and 54 years of age (median age 25 years), who attended the Department of Dermatology and Venereology, University Hospital, Lund, during two periods, namely, June to August 1977 (96 men) and August to October 1978 (156 men). Of the 252 men, 178 $(70.6 \%)$ had symptoms suggesting urethritis, that is, urethral discharge, or dysuria, or both (Group 1). The remaining $74(29 \cdot 4 \%)$ men were symptomless (Group 2). The most common reason for the latter patients attending the clinic was that a sexually transmitted disease had been diagnosed in their sexual partner(s). 


\section{CONTROLS}

Group 3

Fifty-six male medical students and male laboratory staff (20 to 37 years of age, median age 25 years) were studied during the same periods as the men in groups 1 and 2. None of these persons, according to a detailed questionnaire, currently had or had previously had a history of genitourinary disease.

\section{SAMPLING TECHNIQUE AND ISOLATION \\ PROCEDURES}

Urethral specimens from the 252 men in groups 1 and 2 were cultured for Staph. saprophyticus, $C$. trachomatis, and N. gonorrhoeae, while those from the men in group 3 were cultured only for Staph. saprophyticus.

\section{Staphylococcus saprophyticus}

A urethral specimen was collected with the aid of a cotton-tipped swab, which was first used to inoculate a gonococcal medium, and then transferred to a selective medium (Hovelius and Mårdh, 1977a) of the following composition: tryptone broth (Oxoid), $\mathrm{pH}$ $7 \cdot 2$, with the addition of $150 \mu \mathrm{g}$ nalidixic acid (Winthrop) and $2 \mu \mathrm{g}$ novobiocin (Sigma) per ml. In 156 of the patients the swab was also used to inoculate blood agar plates before it was transferred to the broth medium. The broth was incubated at $37^{\circ} \mathrm{C}$ for 18 hours before being seeded on to fresh blood agar plates; these consisted of Blood Agar Base No. 2 (Oxoid) with 4\% defibrinated horse blood. The plates were read after 24 hours' incubation at $37^{\circ} \mathrm{C}$; from each plate at least six staphylococcal colonies were selected for further studies.

The staphylococci were tested for coagulase production. Coagulase-negative strains were tested by disc diffusion tests (see below) for their susceptibility to novobiocin. Strains producing an inhibitory zone of less than $15 \mathrm{~mm}$ in diameter when discs containing $5 \mu \mathrm{g}$ novobiocin were used were considered to be resistant (Hovelius and Mårdh, 1977b). Such strains were further classified as to species by biochemical tests according to Kloos and Schleifer (1975) and the Subcommittee on Taxonomy of Staphylococci and Micrococci (1976). Furthermore, all strains were also tested on agar plates containing glycerol and erythromycin (Schleifer and Kloos, 1975) to establish that the strains tested were staphylococci and not micrococci.

\section{Neisseria gonorrhoeae}

Urethral specimens for the culture of gonococci were collected with a cotton-tipped swab, which, immediately after sampling, was used to inoculate a haematin agar medium (Mårdh et al., 1978). After inoculation, the plate was incubated at $37^{\circ} \mathrm{C}$ with regulated $\mathrm{CO}_{2}$ atmosphere and humidity. The methods used to identify $N$. gonorrhoeae were reported earlier (Mårdh et al., 1978).

\section{Chlamydia trachomatis}

Specimens for the culture of chlamydiae were collected by means of a calcium-alginate swab (Inolex Corp., Glenwood, Illinois, USA), which was gently rotated $2-3 \mathrm{~cm}$ into the urethra before withdrawal. The swabs were transported in a sucrosephosphate buffer (Gordon et al., 1969) supplemented with gentamicin $10 \mu \mathrm{g}$ (Schering), amphotericin B 2.5 $\mu \mathrm{g}$ (Squibb), and vancomycin $100 \mu \mathrm{g}$ (Upjohn) per $\mathrm{ml}$. The specimens were stored at $4^{\circ} \mathrm{C}$ if the culture could be started within 24 hours of sampling; otherwise they were stored at $-20^{\circ} \mathrm{C}$ until required. C. trachomatis was isolated on cycloheximide-treated McCoy cells as described elsewhere (Ripa and Mårdh, 1977).

\section{MICROSCOPY}

Urethral smears from all men in groups 1 and 2 were heat-fixed and stained with methylene blue for the detection of leucocytes and gonococci. The number of leucocytes per high power field (HPF) $(\times 100$ objective) in each smear was graded as follows: $<10$, 10-30, and $>30$ (mean of ten HPFs). All specimens were studied under the same microscope by four different physicians.

\section{ANTIBIOTIC SUSCEPTIBILITY TESTS}

The 48 strains of Staph. saprophyticus isolated from the men in groups 1 and 2 were tested for their susceptibility to penicillin $\mathrm{V}$, cephalexin, nalidixic acid, oxytetracycline, sulphadimidine, and sulphamethoxazole/trimethoprim by the disc diffusion technique (Ericsson and Sherris, 1971) using Wellco susceptibility test agar. The medium and the antibiotic discs were purchased from AB Biodisk (Stockholm, Sweden).

All 48 strains were also tested for $\beta$-lactamase production by means of chromogenic cephalosporin (O’Callaghan et al., 1972).

TREATMENT AND FOLLOW-UP

All patients in whom gonorrhoea was diagnosed by microscopy of urethral discharge were treated with pivampicillin $1.4 \mathrm{~g}$ orally (Pondocillin $\mathrm{R}$, Löwens, Denmark) and probenecid $1 \mathrm{~g}$ (ProbecidR, Astra, Sweden). Patients in whom microscopical examination of urethral discharge did not indicate gonorrhoea but in whom cultures were nevertheless positive for $N$. gonorrhoeae, whether or not Staph. saprophyticus or $C$. trachomatis had been isolated, received the same treatment when re-examined one 
week after the first attendance. If $C$. trachomatis had been isolated, whether or not $N$. gonorrhoeae or Staph. saprophyticus had been isolated, the patients were prescribed lymecycline $\mathbf{0 . 3} \mathrm{g}$ (TetralysalR, Carlo Erba, Italy) twice daily for one week at the first reexamination. In men who had symptoms of urethritis and from whom Staph. saprophyticus-but not $C$. trachomatis or $N$. gonorrhoeae-had been isolated, phenoxymethylpenicillin $0.65 \mathrm{~g}$ (Kåvepenin R, Kabi, Sweden) was given three times daily for 10 days.

At the first, as well as at subsequent, follow-up examinations (which were carried out about one week after the first visit and one week after treatment) all culture studies were repeated.

\section{STATISTICAL METHOD}

All the statistical calculations were performed using the $\chi^{2}$ method with Yates's correction. The degree of freedom for each $P$ value given was one.

\section{Results}

ISOLATION OF MICRO-ORGANISMS

Staph. saprophyticus was isolated from $37(20 \cdot 8 \%)$ of the men in group 1, who had symptoms of urethritis. The corresponding figures for the men in groups 2 and 3 without symptoms were 11 (14.9\%) and four $(7 \cdot 1 \%)$ respectively (Table 1 ).

Table 1 Culture results for urethral samples from 252 men attending a venereal disease clinic

\begin{tabular}{|c|c|c|c|}
\hline \multirow[b]{2}{*}{$\begin{array}{l}\text { Organism } \\
\text { isolated }\end{array}$} & \multicolumn{2}{|l|}{ No. of patients } & \multirow[b]{2}{*}{ Total } \\
\hline & $\begin{array}{l}\text { Symptoms of urethritis } \\
\text { (group l) }\end{array}$ & $\begin{array}{l}\text { Symptomfree } \\
\text { (group 2) }\end{array}$ & \\
\hline $\begin{array}{l}\text { Staph. saprophyticus } \\
\text { C. trachomatis } \\
N . \text { gonorrhoeae } \\
\text { Staph. saprophyticus }\end{array}$ & $\begin{array}{l}25 \\
31 \\
27\end{array}$ & $\begin{array}{r}10 \\
9 \\
3\end{array}$ & $\begin{array}{l}35 \\
40 \\
30\end{array}$ \\
\hline $\begin{array}{l}\text { and } C \text {. trachomatis } \\
\text { and } N \text {. gonorrhoeae }\end{array}$ & $\begin{array}{l}9 \\
3\end{array}$ & $\begin{array}{l}1 \\
0\end{array}$ & $\begin{array}{r}10 \\
3\end{array}$ \\
\hline $\begin{array}{l}\text { C. trachomatis and } \\
N . \text { gonorrhoeae } \\
\text { Total }\end{array}$ & $\begin{array}{r}10 \\
178\end{array}$ & $\begin{array}{r}1 \\
74\end{array}$ & $\begin{array}{r}11 \\
252\end{array}$ \\
\hline
\end{tabular}

Staph. saprophyticus was isolated from only six of 156 urethral specimens collected from men in groups 1 and 2 when inoculated directly on to blood agar plates, while the organism was found in 32 of the same specimens when the selective broth medium was used.

Staph. saprophyticus occurred more often in the men in group 1 than in those in group $3(P<0.05)$, while the difference between the isolation frequency of Staph. saprophyticus in groups 2 and 3 was not significant. This was also true when the isolation frequency in groups 1 and 2 was compared with that in group 3 and when that in groups 1 and 2 was compared.

$N$. gonorrhoeae was found in $22.5 \%$ and $C$. trachomatis in $28.1 \%$ of the men in group 1 ; the corresponding figures in group 2 were $5.4 \%$ and $14.9 \%$ for $N$. gonorrhoeae and $C$. trachomatis respectively.

Staph. saprophyticus was isolated from three $(6.8 \%)$ of the men with gonorrhoea and from 10 $(16.4 \%)$ of the 61 men harbouring $C$. trachomatis (Table 1).

\section{RELATION OF MICROSCOPY AND CULTURE}

RESULTS

The culture results of groups 1 and 2 are related to the number of leucocytes per HPF in urethral smears in Table 2. None of the men from whom more than

Table 2 Number of leucocytes per high power field (HPF) ( $\times 100$ objective) in urethral smears of male patients (groups 1 and 2) in relation to micro-organisms isolated*

\begin{tabular}{|c|c|c|c|c|}
\hline \multirow[b]{2}{*}{ Organism isolated } & \multirow[b]{2}{*}{ No. of patients } & \multicolumn{3}{|c|}{ No. of leucocytes $/ H P F$} \\
\hline & & $<10$ & $10-30$ & $>30$ \\
\hline $\begin{array}{l}\text { Staph. saprophyticus } \\
\text { C. trachomatis } \\
\text { N. gonorrhoeae } \\
\text { Negative results } \\
\text { for all three }\end{array}$ & $\begin{array}{l}35 \\
40 \\
28\end{array}$ & $\begin{array}{r}15 \\
9 \\
2\end{array}$ & $\begin{array}{r}11 \\
9 \\
6\end{array}$ & $\begin{array}{r}9 \\
22 \\
20\end{array}$ \\
\hline organisms & 123 & 82 & 21 & 20 \\
\hline
\end{tabular}

*Men from whom more than one of the three organisms was isolated are not included

one of the three organisms were isolated is included in the Table. Staph. saprophyticus $(\mathrm{P}<0.05), N$. gonorrhoeae $(\mathrm{P}<0.001)$, and $C$. trachomatis $(\mathrm{P}<0.001)$ all occurred significantly more often in those men who had more than 10 leucocytes per HPF than in those with fewer. Approximately one-third of the men from whom none of these organisms was recovered also had more than 10 leucocytes per HPF. This was also true for most $(20 / 35)$ of those infected with Staph. saprophyticus.

\section{RELATION OF SYMPTOMS AND CULTURE RESULTS}

The symptoms reported by the men in group 1 are related to the culture results in Table 3. Only those

Table 3 Symptoms of men with urethritis (group I) in relation to micro-organism isolated from urethral specimens*

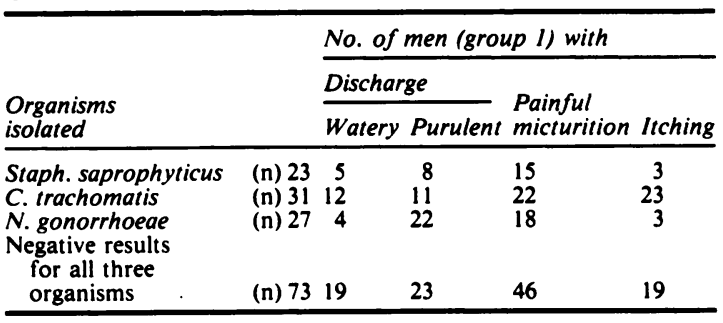

*Men from whom more than one of the three organisms was isolated are not included 
men who harboured one of the three organisms are presented in the Table. Among the men who had symptoms, discharge was reported more often in those with gonorrhoea than in those infected with $C$. trachomatis or Staph. saprophyticus. Watery discharge was reported more often by men with chlamydial infection than by those with gonorrhoea, while the converse was true for purulent discharge. There was no significant difference regarding the occurrence of purulent or watery discharge in men from whom C. trachomatis and Staph. saprophyticus were isolated and from those in whom these organisms or gonococci could not be demonstrated. Dysuria was reported with approximately the same frequency regardless of the result of the culture studies.

\section{ANTIBIOTIC SUSCEPTIBILITY AND}

CHROMOGENIC CEPHALOSPORIN TESTS

The disc diffusion tests indicated that, except for four strains, Staph. saprophyticus was susceptible to all the antibiotics tested, although all strains were resistant to nalidixic acid (Table 4). The strains did not produce $\beta$-lactamases according to the results of the chromogenic cephalosporin test.

Table 4 Antibiotic susceptibility of 48 strains of Staphylococcus saprophyticus isolated from urethral specimens of men attending a venereal disease clinic (groups 1 and 2)

\begin{tabular}{lllr}
\hline Antibiotic & Susceptible & Intermediate & Resistant \\
\hline Penicillin V & 48 & & \\
Cephalexin & 48 & & 48 \\
Nalidixic acid & 0 & & 3 \\
Oxytetracycline & 45 & 2 & 2 \\
Sulphadimidine & 44 & & \\
Sulphamethoxazole/ & & & \\
trimethoprim & 48 & & \\
\hline
\end{tabular}

\section{TRE ATMENT}

In 12 of the 16 men in group 1 harbouring Staph. saprophyticus and who returned for re-examination, this organism could not be isolated, irrespective of whether phenoxymethylpenicillin, lymecycline, or pivampicillin had been given. All 16 men had become symptomfree. In one of the four men with persistent growth of Staph. saprophyticus, a renal calculus was later diagnosed. In another four men (one from group 1 and three from group 2) harbouring Staph. saprophyticus, and who had not been given antibiotics, the organism could no longer be isolated from urethral specimens at re-examination two weeks after the initial examination.

None of the 44 men in groups 1 and 2 with gonorrhoea was culture-positive for $N$. gonorrhoeae after treatment and 42 were symptomfree. Thirtytwo of the 61 chlamydia-positive men returned for follow up. All of them had become culture-negative for C. trachomatis and 29 were symptomfree.

\section{Discussion}

Staph. saprophyticus is a common cause of acute, often haemorrhagic, cystourethritis in young adult women (Maskell 1974; Sellin et al., 1975). Urinary tract infections with Staph. saprophyticus in women occur most frequently in those age groups in which the highest incidence of sexually transmitted genital infections occur. A seasonal variation in the incidence of such infections has been noted; the highest incidence occurs in early autumn (Telander and Wallmark, 1975; Maskell and Pead, 1977; Hovelius and Mårdh, 1978), that is during the same period of the year as the present study was undertaker. A similar variation can also be shown for most sexually transmitted infections (Wright and Judson, 1978), but this cannot be demonstrated for urinary tract infections caused by Escherichia coli (Maskell and Pead, 1977).

In men, cystitis with Staph. saprophyticus most frequently occurs in men over 60 years of age with benign hyperplasia of the prostate. However, we have observed acute cystitis caused by Staph. saprophyticus, in young adult men without obstructive urinary tract disease (Hovelius and Mårdh, 1978). Some of these men had attended a venereal disease clinic because they suspected that they had contracted a venereal infection.

Staph. saprophyticus is known to occur as a pathogen solely in the urinary tract. In clinical microbiological laboratories, Staph. saprophyticus is seldom recovered from specimens other than urine, in which it rarely seems to occur as a contaminant. Staph. saprophyticus may be isolated from the skin of the arms and legs, although transiently and in low numbers (Kloos and Musselwhite, 1975). With a selective culture medium, Pead and Maskell (1977) isolated Micrococcus subgroup III from rectal swabs from 10 of 156 women.

It has been argued that the capacity of a bacterium to adhere to epithelial cells is a prerequisite for its ability to cause mucosal infections (Gibbons, 1977). In in vitro experimental studies on bacterial adhesion to urothelial cells, we found Staph. saprophyticus to adhere in significantly greater numbers to such cells than to epithelial cells from other sites, for example, buccal and skin cells (Colleen et al., in press). Among other genital and urinary tract pathogens only freshly isolated strains of $N$. gonorrhoeae, producing $\mathrm{T} 1$ and T2 colonies, adhered in greater numbers per urothelial cell than did Staph. saprophyticus. This pronounced capacity of Staph. saprophyticus to 
adhere to urothelial cells may explain the organism's tropism for the urinary tract (Mårdh et al., 1979).

When urethral specimens are cultured on blood agar, Staph. saprophyticus is seldom isolated, as shown in the present study. Bowie et al. (1977b) failed to isolate this organism from any of 62 patients with NGU. The poor growth of Staph. saprophyticus on blood agar plates inoculated with urethral specimens might be because this bacterium occurs in low numbers or because it is inhibited by microbial interaction. Thus, we have found that strains of Staph. epidermidis may inhibit growth of Staph. saprophyticus on artificial culture media (unpublished data).

When our selective culture medium was used, Staph. saprophyticus could be isolated from the urethral specimens of men without either a history or symptoms of urethritis or urinary tract infection. Thus, the organism was recovered from $7 \cdot 1 \%$ of male students and laboratory staff.

The role of Staph. saprophyticus in NGU is difficult to establish, as is that of other organisms which may occur in the normal flora, namely $U$. urealyticum. Staph. saprophyticus was isolated significantly more often from the men with symptoms of urethritis (group 1) than from medical students and laboratory staff (group 3). The organism was found significantly more often among the men in groups 1 and 2 with an increased number of leucocytes in their urethral smears than in those men in these groups with less than 10 leucocytes per HPF. It is notable that in the patients with gonorrhoea the frequency of isolation of Staph. saprophyticus was as low as in the men in group 3.

Staph. saprophyticus was susceptible in vitro to all antibiotics tested, including a number of drugs commonly prescribed to men with genital and urinary tract infections. In this respect, however, nalidixic acid was an exception (Hovelius and Mårdh, 1977b). In a previous study this antibiotic constantly failed to cure patients with urinary infection caused by Staph. saprophyticus (Hovelius et al., 1979). Of the 16 men studied who harboured Staph. saprophyticus, and who were treated with penicillin, pivampicillin or lymecycline, 12 were culture-negative and symptomfree at follow up. Three men still harboured Staph. saprophyticus but had no symptoms and less than 10 leucocytes per HPF in urethral smears at re-examination. In one man, in whom Staph. saprophyticus persisted despite antibiotic treatment, a renal calculus was diagnosed. This observation agrees with our earlier findings (Hovelius et al., 1979). We have occasionally diagnosed persistent bacteriuria with Staph. saprophyticus which proved intractable to repeated courses of antibiotics to which the organism was susceptible in vitro. These men became culturenegative after the removal of the calculus.

The finding that Staph. saprophyticus and symptoms of urethritis had disappeared within a fortnight in some men not given antibiotic treatment agrees with the observation of spontaneous cure in women of urinary tract infections caused by coagulase-negative staphylococci (Mabeck, 1969).

In conclusion, the result of the present study suggests that Staph. saprophyticus should be considered as a potential aetiological agent of some cases of NGU in men.

This study was supported by grant No. 16X-4509 from the Swedish Medical Research Council.

\section{References}

Alani, M. D., Darougar, S., MacD. Burns, D. C., Thin, R. N., and Dunn, H. (1977). Isolation of Chlamydia trachomatis from the male urethra. British Journal of Venereal Diseases, 53, 88-92.

Bowie, W. R., Wang, S. P., Alexander, E. R., Floyd, J., Forsyth, P. S., Pollock, H. M., Lin, J-S. L., Buchanan, T. M., and Holmes, K. K. (1977a). Etiology of nongonococcal urethritis. Evidence for Chlamydia trachomatis and Ureaplasma urealyticum. Journal Clinical Investigation, 59, 735-742.

Bowie, W. R., Wang, S-P., Alexander, E. R., and Holmes, K. K. (1977b). Etiology of nongonococcal urethrithis. In Nongonococcal Urethritis and Related Infections, p. 19. Edited by D. Hobson, and K. K. Holmes. American Society for Microbiology: Washington DC.

Catterall, R. D. (1975). The situation of gonococcal and nongonococcal infections in the United Kingdom. In Genital infections and their complications, p. 5 . Edited by D. Danielsson, L. Juhlin, and P.-A. Mårdh. Almqvist \& Wiksell, International: Stockholm (Sweden).

Colleen, S., Hovelius, B., Wieslander, A., and Mărdh, P.-A. (1979). Surface properties of Staphylococcus saprophyticus and Staphylococcus epidermidis as studied by adherence tests and twopolymer aqueous phase systems. Acta Pathologica et Microbiologica Scandinavica, Section B, in press.

Ericsson, H. and Sherris, J. C. (1971). Antibiotic sensitivity testing. Report on an international collaborative study. Acta Pathologica et Microbiologica Scandinavica, Section B, Suppl. No. 217.

Gibbons, R. J. (1977). Adherence of bacteria to host tissue. Position paper. In Microbiology-1977, p. 395. Edited by D. Schlessinger. American Society for Microbiology: Washington DC.

Gordon, F. B., Harper, I. A., Quan, A. L., Treharne, J. D., Dwyer, R. St C., and Garland, J. A. (1969). Detection of Chlamydia (Bedsonia) in certain infections of man. I. Laboratory procedures: comparison of yolk sac and cell culture for detection and isolation. Journal of Infectious Diseases, 120, 451-462.

Holmes, K. K., Handsfield, H. H., Wang, S-P., Wentworth, B. B., Turck, M., Anderson, J. B., and Alexander, E. R. (1975). Etiology of nongonococcal urethritis. New England Journal of Medicine, 292, 1999-1205.

Hovelius, B. and Mårdh, P-A. (1977a). Acute cystourethritis caused by Staphylococcus saprophyticus-a sexually transmitted disease? The Medical Women's International Association for the Northern European Countries, Fourth Congress. Abstract, p. 19.

Hovelius, B. and Mărdh, P-A. (1977b). On the diagnosis of coagulase-negative staphylococci with emphasis on Staphylococcus saprophyticus. Acta Pathologica et Microbiologica Scandinavica, Section B, 85, 427-434.

Hovelius, B. and Mårdh, P-A. (1978). Urogenital infections caused by Staphylococcus saprophyticus. In Proceedings of the Medical Women's International Association for the Northern European Countries, Fourth Congress. Astra-Syntex, Stockholm.

Hovelius, B., Mårdh, P-A., and Bygren, P. (1979). Urinary tract infections caused by Staphylococcus saprophyticus-recurrences and complications. Journal of Urology, 122, in press. 
Kioos, W. E. and Schleifer, K. H. (1975). Simplified scheme for routine identification of human Staphylococcus species. Journal of Clinical Microbiology, 1, 82-88.

Kloos, W. E. and Musselwhite, M. S. (1975). Distribution and persistence of Staphylococcus and Micrococcus species and other aerobic bacteria on human skin. Applied Microbiology, 30, 381-395.

Mabeck, C. E. (1969). Significance of coagulase-negative staphylococcal bacteriuria. Lancet, 2, 1150-1152.

Maskell, R. (1974). Importance of coagulase-negative staphylococci as pathogens in the urinary tract. Lancet, 2, 1155-1158.

Maskell, R. and Pead, L. (1977). Micrococci and urinary infection. Lancet, 2, 1224.

Mårdh, P-A., Mårtensson, D., and Soltesz, L. V. (1978). An effective simplified medium for the culture of Niesseria gonorrhoeae. Sexually Transmitted Diseases, 5, 10-13.

Mårdh, P-A., Colleen, S., and Hovelius, B. (1979). Attachment of bacteria to exfoliated cells from the urogenital tract. Investigative Urology, 16, 322-326.

O'Callaghan, C. H., Morris, A., Kirby, S. M., and Shingler, A. H. (1972). Novel method for detection of $\beta$-lactamases by using a chromogenic cephalosporin substrate. Antimicrobial Agents and Chemotherapy, 1, 283-288.

Oriel, J. D., Reeve, P., Wright, J. T., and Owen, J. (1976). Chlamydial infection of the male urethra. British Journal of Venereal Diseases, 52, 46-51.

Pead, L. and Maskell, R. (1977). 'Micrococci' and urinary infection. Lancet, 2, 565.
Prentice, M. J., Taylor-Robinson, D., and Csonka, G. W. (1976). Non-specific urethritis. A placebo-controlled trial of minocycline in conjunction with laboratory investigations. British Journal of Venereal Diseases, 52, 269-275.

Ripa, K. T. and Mårdh, P-A. (1977). Cultivation of Chlamydia trachomatis in cycloheximide-treated McCoy cells. Journal of Clinical Microbiology, 6, 328-331.

Ripa, K. T., Mårdh, P-A., and Thelin, I. (1978). Chlamydia trachomatis urethritis in men attending a venereal disease clinic. Acta Dermatovenereologica (Stockholm), 58, 175-179.

Schleifer, K. H. and Kloos, W. E. (1975). A simple test system for the separation of staphylococci and micrococci. Journal of Clinical Microbiology, 1, 337-338.

Sellin, M., Cooke, D. I., Gillespie, W. A., Sylvester, D. G. H., and Andersson, J. O. (1975). Micrococcal urinary tract infections in young women. Lancet, 2, 570-572.

Subcommittee on Taxonomy of Staphylococci and Micrococci (1976). Minutes of the meeting, 9 September 1975. International Journal of Systematic Bacteriology, 26, 332-334.

Telander, B. and Wallmark, G. (1975). Micrococcus subgroup 3a common cause of acute urinary tract infection in women. Lakartidningen (Stockholm), 72, 1675-1677.

Wright, R. A. and Judson, F. N. (1978). Relative and seasonal incidences of the sexually transmitted diseases. British Journal of Venereal Diseases, 54, 433-440. 